\section{Analysis of Dentistry YouTube Videos Related To COVID-19}

Melih Ozdede ${ }^{1} \odot$, Ilkay Peker²®

This study aimed to analyze the videos available on YouTube related to dentistry and the novel coronavirus (COVID-19), as there is no such analysis in the existing literature. The terms "dental" and "COVID-19" were searched on YouTube on May 9, 2020. The top 116 English-language videos with at least 300 views were analyzed by two observers. Data was saved for each video, including target audience, source, country of origin, content, number of views, time watched, average views, duration, like/dislike ratio, and usefulness. Total video information and quality index (VIOI) scores were calculated, consisting of flow, information, accuracy, quality, and precision indices. Non-parametric tests were used for analysis. The analyzed videos were viewed 375,000 times and totaled $20 \mathrm{~h}$ of content. Most videos were uploaded by dentists (45.7\%), originated from the United States (79.3\%), and contained information targeted towards patients (48.3\%). Nearly half of the videos (47.4\%) were moderately useful. For the usefulness of the videos, statistically significant differences were found for all indices as well as total VIOI scores. A comparison of the indices according to the relevance of the videos showed statistically significant differences in the videos' information and precision indices and total VIOI scores. The results of this study showed that dentistry YouTube videos related to COVID-19 had high view numbers; however, the videos were generally moderate in quality and usefulness.
'Department of Dentomaxillofacial Radiology, Faculty of Dentistry, Pamukkale University, Denizli, Turkey ${ }^{2}$ Department of Dentomaxillofacial Radiology, Faculty of Dentistry, Gazi University, Ankara, Turkey

Correspondence: Melih Ozdede, Kınıklı Campus, 20070, Denizli, Turkey. Tel: 0090-258- 2964486. e-mail: melihozdede@gmail.com

Key Words: COVID-19, communicable diseases, dental education, public health dentistry, social media.

\section{Introduction}

In late 2019, a novel form of coronavirus emerged in Wuhan, China (1). After the virus rapidly spread around the world, the World Health Organization (WHO) declared the disease a pandemic in March 2020 and named it COVID-19 (2). As of June 10,2020, approximately seven million cases of COVID-19 had been reported worldwide, and the death toll had reached 400,000 (3). Common methods of COVID-19 transmission include direct contamination, coughing and sneezing droplet inhalation, and face-to-face contact $(4,5)$.

Dental procedures involve high risk of cross-infection between patients and practitioners (6). During the COVID-19 pandemic, it has been suggested that non-urgent elective procedures be postponed (7). In emergencies, it is necessary to take effective infection control measures in countries affected by COVID-19 (8). The literature indicates that precautions taken in dentistry procedures can prevent COVID-19 infection (4). These precautions include creating pre-control triage, measuring fever with a thermometer before entering the patient clinic, arranging isolation rooms for infected patients, performing only emergency procedures during the epidemic period, complying with hand hygiene, wearing protective equipment, avoiding intraoral imaging, using a pre-procedure oxidative mouthwash, good ventilation, minimizing the use of highspeed devices, caries cleaning and periodontal treatments manually, disinfection more carefully, sufficient knowledge of dental personnel, and other tele-dentistry applications $(4,6,9)$.
One of the most important factors in preventing COVID-19 transmission is sharing accurate information (10). Information can be published and shared without any institutional or equivalent quality control on the internet; therefore, it is entirely the uploader's responsibility to determine whether the shared information is true or false (11). Although the WHO and the Centers for Disease Control and Prevention have published a great deal of content online for this purpose, the spread of misinformation is also increasing (3). YouTube (an online video-sharing platform) is the second most popular website worldwide (12). During the Ebola and Zika virus pandemics, the millions of times that informational videos were watched on YouTube demonstrated the importance of this platform in disseminating information $(13,14)$. The terms "coronavirus" and "COVID-19" became the most searched words on Google and YouTube in the first four months of 2020 (15). It is important for dentists to be aware of the content and quality of the COVID-19 information provided online and to create accurate and efficient data sources that can be used to counsel patients (16).

Although three recent studies about COVID-19 preventive behaviors in the context of YouTube have been conducted, to the best of our knowledge, there has been no study focusing specifically on dentistry-related YouTube videos in this area $(10,17,18)$. The purpose of this study is to analyze YouTube videos related to dentistry and COVID-19 as a source of medical information. 


\section{Material and Methods}

This study was approved by the Ministry of Health, Republic of Turkey (No: 2020-05-20T17_22_42).

Based on the Cohen's effect size (0.40 effect size), 85\% power, and 0.05 error margin, 116 was calculated as the total sample size, using the $\mathrm{G}^{*}$ Power software, version 3.1.9.2.

The researchers accessed YouTube on May 9, 2020. A new account was created for this study, and the terms "dental" + "COVID-19" were searched. Since the term "dental" is more inclusive compared to the term "dentistry", the term "dental" was used in the search. Only English-language videos that had at least 300 views and were uploaded after January 2020 were included in this study; videos in languages other than English were excluded (19). One of the videos included was uploaded more than once. The URLs of the first 116 results matching the study criteria in decreasing order of "relevance" were saved electronically due to daily changes. If a video offered subtitles, subtitles were used to improve understanding. All videos were reviewed and analyzed by two dentomaxillofacial radiologists with eight (M.O.) and twenty (I.P.) years of clinical experience, for interobserver reliability. For intra-observer reliability, the first observer viewed half of the videos $(n=58)$ a second time.

\section{Assessment of Content}

The following data were saved for each video: target audience (dentists and patients); source (official institution [American Dental Association, WHO, etc.]; country of origin (United States of America, India, England, Canada, and other); main content (general information about COVID-19, infection control measures, dental emergencies, patient information, or legal/financial issues); number of views; time watched (elapsed day after video upload); average views per day; duration (in minutes); like/dislike ratio; and usefulness. To assess the value of the videos of the contents, a "usefulness score" was designed to categorize each video. The scoring was modified from the previous YouTube studies related to dentistry, by consensus of three specialist dentists at least 10 years of experience $(20,21)$. The videos were evaluated in terms of the symptoms, transmission routes, and protection of COVID-19, dental infection control measures, patient informing, dental emergencies, tele-dentistry, and legal/financial issues. Each item was scored as one-point. The scores ranged from 0 to 8: Scores between 0 and 2 were classified as less useful, 3 to 5 were moderately useful, and scores between 6 and 8 were extremely useful. The first 58 videos were considered high-relevance (HR), and the second 58 were considered low-relevance (LR).

The video information and quality index (VIOI) was used to determine video quality $(16,22)$. The $\mathrm{VIOI}$, consisting of the contents in the Global Quality Scale (GOS), is used to evaluate the overall quality of the videos (16). The contents of the index included flow, information accuracy, quality (images, animations, interviews, subtitles, and summary), and precision (title-content compatibility) indices. Each component of the VIOI score was evaluated using a 5-point Likert scale ranging from 1 (poor quality) to 5 (high quality). The equivalents of the scores were made according to the following criteria: Score 1: poor quality, poor flow, most information missing, not useful; Score 2: generally poor quality, poor flow, very limited information; Score 3: moderate quality, moderate flow, some important information is available but others are not, somewhat useful, Score 4: good quality, good flow, most of the relevant information is available, but there are deficiencies in the topics, useful, Score 5: excellent quality, excellent flow, very useful (23).

\section{Statistical Analysis}

The NCSS 2007 software package (Kaysville, Utah, United States) was used for statistical analysis. Descriptive statistics (mean, standard deviation, median, frequency, rate, minimum, and maximum) were performed, and the distribution of the data were calculated using the ShapiroWilk test. The Kruskal-Wallis test was used to compare three or more groups of quantitative data that were not normally distributed, and the Mann-Whitney U test was used to compare two groups that were not normally distributed. For intra-observer reliability, the Wilcoxon test was used to compare periodic quantitative data ( $\mathrm{VIOI}$ scores), and the McNemar test was used for qualitative data (usefulness). For inter-observer reliability, the Mann-Whitney $U$ test was used to compare quantitative data, and the chi-squared test was used to compare qualitative data. For correlation of data, Spearman's test was performed. Significance was evaluated at the $p<0.05$ level.

\section{Results}

\section{Distribution of Data}

The total duration of all analyzed videos was approximately $20 \mathrm{~h}$. These 116 videos attracted a total of 375.000 views. More detail regarding the distribution of the data is provided in Table 1.

The duration of the videos ranged from 1 minute to $97 \mathrm{~min}$, and the total $\mathrm{VIOI}$ scores ranged from 1 to 20 . Video quality indices and total VIOI scores averages were moderate. The descriptive analysis of the characteristics and quality of the videos is summarized in Table 2.

\section{Comparison of the Indices}

Table 3 presents the comparison of indices according to target audience, source, country of origin, content, usefulness, and relevance. In terms of target audience, it 
was found statistically significant that the flow $(p=0.002)$, information ( $p=0.001)$, and quality $(p=0.024)$ indices and total VIOI scores $(\mathrm{p}=0.001)$ of videos intending dentists were higher than these for patients. When videos were compared by source, there were statistically significant differences in the flow $(p=0.012)$ and information $(p=0.001)$ indices and total VIOI scores $(p=0.017)$. The level of information received from official institutions was statistically higher than dentists ( $p=0.001)$. In terms of video content, there were statistically significant differences in flow $(p=0.028)$, information ( $p=0.001)$, and quality $(p=0.043)$ indices and total VIQI scores $(p=0.001)$. The information indices and total $\mathrm{VIOI}$ scores of the patient informing videos were found to be statistically lower compared to infection control measures and legal-financial issues $(p=0.001)$. It was revealed that the flow $(p=0.144)$, information $(p=0.023)$, and precision $(p=0.009)$ indices and total $\mathrm{VIOI}$ scores $(p=0.021)$ of HR videos were statistically higher than LR.

Table 1. Distribution of the target, source, country of origin, content, and usefulness* of 116 most popular English-language COVID-19related videos

\begin{tabular}{|c|c|c|c|}
\hline Variables & & $\mathrm{n}$ & $\%$ \\
\hline \multirow{2}{*}{$\begin{array}{l}\text { Target audience } \\
\text { of the videos }\end{array}$} & Dentists & 56 & 48.3 \\
\hline & Patients & 60 & 51.7 \\
\hline \multirow{4}{*}{ Source of the videos } & Official institutions & 32 & 27.6 \\
\hline & Dentists & 53 & 45.7 \\
\hline & News agencies & 26 & 22.4 \\
\hline & Other & 5 & 4.3 \\
\hline \multirow{5}{*}{$\begin{array}{l}\text { Country of origin } \\
\text { of the videos }\end{array}$} & United States & 92 & 79.3 \\
\hline & India & 5 & 4.3 \\
\hline & England & 5 & 4.3 \\
\hline & Canada & 3 & 2.6 \\
\hline & Other & 11 & 9.5 \\
\hline \multirow{5}{*}{$\begin{array}{l}\text { Content of } \\
\text { the videos }\end{array}$} & Information about COVID-19 & 7 & 6 \\
\hline & Infection control measures & 40 & 34.5 \\
\hline & Dental emergencies & 8 & 6.9 \\
\hline & Patient informing & 56 & 48.3 \\
\hline & Legal-financial issues & 5 & 4.3 \\
\hline \multirow{3}{*}{$\begin{array}{l}\text { Usefulness of } \\
\text { the videos }\end{array}$} & Less useful & 28 & 24.1 \\
\hline & Moderately useful & 55 & 47.4 \\
\hline & Extremely useful & 33 & 28.4 \\
\hline
\end{tabular}

*Usefulness scores between 0 and 2 were classified as less useful, 3 to 5 were moderately useful, 6 to 8 were extremely useful.

\section{Correlation Analysis}

The correlation analysis of the data is presented in Table 4. For the indices and total $\mathrm{VIOI}$ score, the correlations varied positively between weakly to extreme relationships $(p=0.001)$.

\section{Reliability Analysis}

Regarding the usefulness of the videos and total VIOI scores; no statistically significant difference was detected for either intra-observer $(p=0.135$ and $p=0.059)$ or interobserver reliability $(p=0.966$ and $p=0.897)$, respectively.

\section{Discussion}

Scientific accuracy and quality of medical information on the internet are very variable. The shared information is directly published without any quality control; therefore, the accuracy of the shared information is entirely the initiative and responsibility of the uploader (11). This situation leads to a significant level of information pollution as well as useful information. In literature, there are various published articles regarding the content of YouTube videos on many topics $(13,14,16)$.

The present study is the first analysis to focus on dentistry-related YouTube videos that discuss COVID-19. Currently, only three studies have been published about YouTube and COVID-19 $(10,17,18)$. Basch et al. (10) evaluated COVID-19 videos in terms of the information

Table 2. Descriptive analysis of the characteristics and quality of 116 most popular English-language COVID-19-related videos

\begin{tabular}{lccc}
\hline & Variables & Mean \pm SD & $\begin{array}{c}\text { Min-Max } \\
\text { (Median) }\end{array}$ \\
\hline & $\begin{array}{c}\text { Number } \\
\text { of views } \\
\text { Upload time } \\
\text { (days) }\end{array}$ & $3229.6 \pm 5356.92$ & $\begin{array}{c}302-27962 \\
(841.5)\end{array}$ \\
$\begin{array}{l}\text { Characteristics } \\
\text { of the videos }\end{array}$ & $\begin{array}{c}\text { Average views } \\
\text { (per day) }\end{array}$ & $207.46 \pm 517.6$ & $8-4955(52)$ \\
& $\begin{array}{c}\text { Duration } \\
\text { (minute) }\end{array}$ & $10.28 \pm 16.92$ & $1-97(3)$ \\
& $\begin{array}{c}\text { Like/dislike } \\
\text { ratio }\end{array}$ & $10.85 \pm 11.01$ & $1-49(6.5)$ \\
& Flow & $2.99 \pm 1$ & $1-5(3)$ \\
$\begin{array}{l}\text { Video } \\
\text { information } \\
\text { and quality } \\
\text { indices }\end{array}$ & Information & $3.31 \pm 0.98$ & $1-5(3)$ \\
& Puality & $2.97 \pm 0.91$ & $1-5(3)$ \\
& Precision & $3.93 \pm 0.97$ & $1-5(4)$ \\
\hline & Total VIQI & $13.21 \pm 3.23$ & $5-20(14)$ \\
\hline
\end{tabular}

SD: Standard deviation, VIQI: Video information and quality index. 
they provided about prevention behaviors, symptoms, and disease transmission. They reported that most videos did not discuss suggested prevention behaviors, symptoms, and transmission, with most instead referring to quarantine and travel restrictions. The same authors conducted another YouTube study, this time focusing on the periodic change in videos on behaviors to alleviate COVID-19 transmission (17). According to the video analysis, which was conducted at two-month intervals, the total number of video views tripled, although the content related to COVID-19 prevention behaviors did not vary significantly. In another study, Khatri et al. (18) analyzed the contents

Table 3. Comparison of indices according to target, source, country of origin, content, usefulness, and relevance of the videos

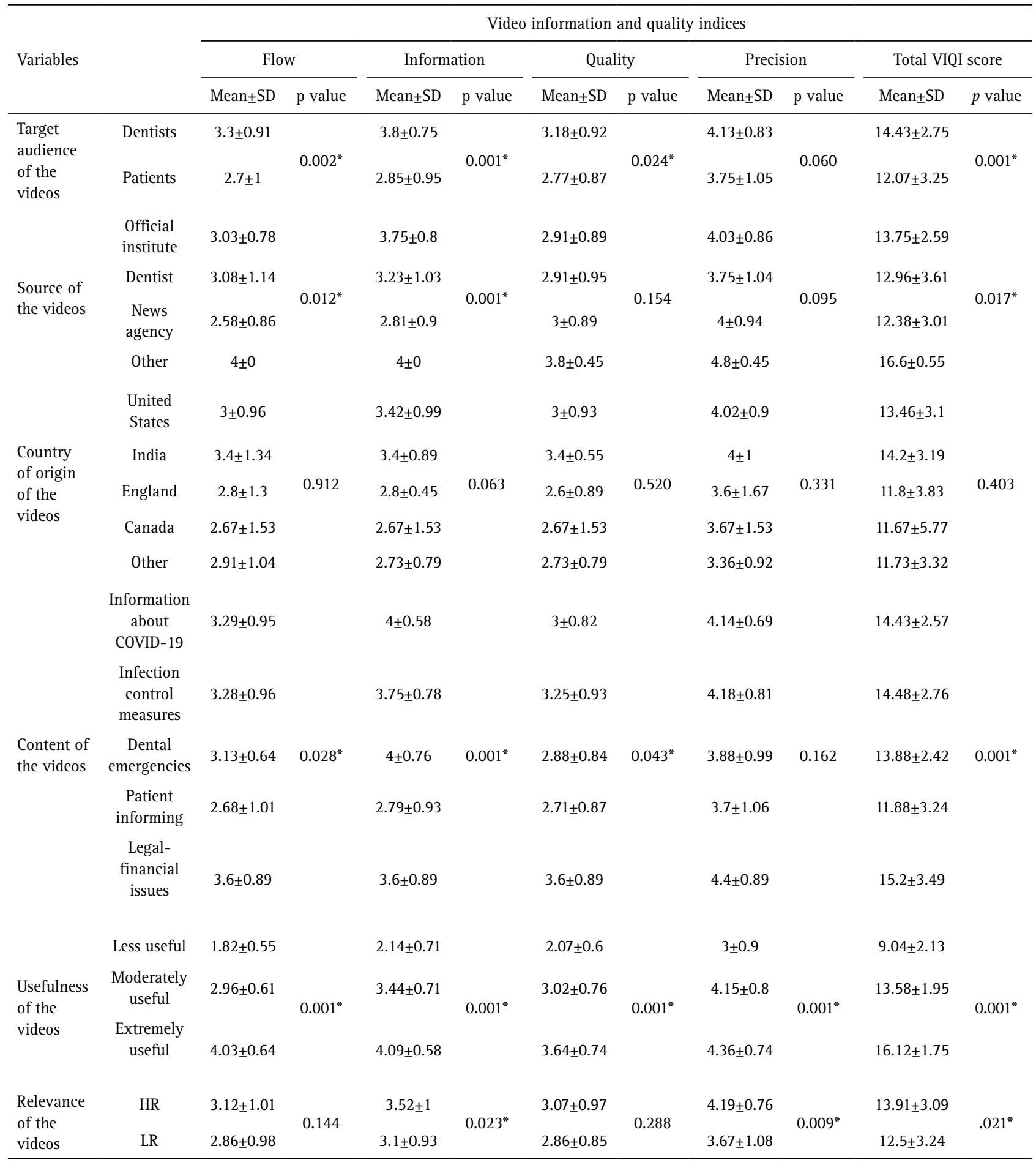

Kruskal Wallis test, Mann Whitney U test, ${ }^{*}$ p $<0.05$. SD: Standard deviation, VIQI: Video information and quality index, HR: High relevance, LR: Low relevance. 
of English-language and Mandarin-language COVID-19 videos on YouTube. English-language videos had more content related to prevalence and testing, while Mandarinlanguage videos had better content related to clinical symptoms. In our current study, patient informing, and infection control measures were the major contents. The information level and quality of 'patient informing' videos were found to be low. This result reveals the need to upload more high-quality videos to YouTube related to patient information about COVID-19. Similarly, since the number of videos about 'dental emergencies' and 'legal-financial issues' to be made during the COVID-19 pandemic is low, there is a need for more videos to be prepared for these contents. Informing both healthcare professionals and patients about these contents will be important for public health. Khatri et al's study also found that mean medical information and content index (MICl) scores were low for videos in both languages (6.71, and 6.28, respectively) (18). Although we did not use the $\mathrm{MICl}$ in our study, the total scores of the VIOI index we used were high compared to the previous study.

In a 2012 study of YouTube videos about West Nile virus, $41.8 \%$ of videos originated from news agencies (22). A similar result (41.9\%) was reported in a 2014 analysis of videos about Ebola hemorrhagic fever (16). In our study, $22.4 \%$ of videos originated from news agencies. Considering that news agencies were the group with the lowest information and total video quality index in our study, the decrease in the ratio of videos produced by this group can be considered promising. It would be beneficial for official institutions that are the source of more highly informative videos to increase their focus on this powerful platform.

Previous YouTube studies have used other video quality indexes, like the modified Discern index and the

Table 4. Correlation analysis of the data

\begin{tabular}{|c|c|c|c|c|c|c|c|c|c|c|c|}
\hline Variables & & $\begin{array}{l}\text { Number } \\
\text { of views }\end{array}$ & $\begin{array}{l}\text { Upload } \\
\text { time }\end{array}$ & $\begin{array}{l}\text { Average } \\
\text { views }\end{array}$ & Duration & $\begin{array}{l}\text { Like/dislike } \\
\text { ratio }\end{array}$ & $\begin{array}{l}\text { Flow } \\
\text { index }\end{array}$ & $\begin{array}{l}\text { Information } \\
\text { index }\end{array}$ & $\begin{array}{l}\text { Quality } \\
\text { index }\end{array}$ & $\begin{array}{c}\text { Precision } \\
\text { index }\end{array}$ & $\begin{array}{c}\text { Total VIQI } \\
\text { score }\end{array}$ \\
\hline \multirow[t]{2}{*}{$\begin{array}{l}\text { Number } \\
\text { of views }\end{array}$} & $\begin{array}{l}\mathrm{r} \\
\mathrm{p}\end{array}$ & $\begin{array}{l}1 \\
.\end{array}$ & & & & & & & & & \\
\hline & $\mathrm{r}$ & 0.062 & 1 & & & & & & & & \\
\hline Upload time & $\mathrm{p}$ & 0.507 & . & & & & & & & & \\
\hline \multirow{2}{*}{$\begin{array}{l}\text { Average } \\
\text { views }\end{array}$} & $\mathrm{r}$ & 0.878 & -0.320 & 1 & & & & & & & \\
\hline & $\mathrm{p}$ & $0.001^{*}$ & $0.001^{*}$ & · & & & & & & & \\
\hline \multirow[b]{2}{*}{ Duration } & $\mathrm{r}$ & .305 & -0.085 & 0.310 & 1 & & & & & & \\
\hline & $\mathrm{p}$ & $0.001^{*}$ & 0.366 & $0.001^{*}$ & . & & & & & & \\
\hline \multirow{2}{*}{$\begin{array}{l}\text { Like/dislike } \\
\text { ratio }\end{array}$} & $\mathrm{r}$ & .536 & 0.088 & 0.425 & 0.473 & 1 & & & & & \\
\hline & $\mathrm{p}$ & $0.001^{*}$ & 0.346 & $0.001^{*}$ & $0.001^{*}$ & . & & & & & \\
\hline \multirow[b]{2}{*}{ Flow index } & $\mathrm{r}$ & 0.155 & -0.014 & 0.125 & 0.329 & 0.211 & 1 & & & & \\
\hline & $\mathrm{p}$ & 0.098 & 0.884 & 0.181 & $0.001^{*}$ & $0.001^{*}$ & . & & & & \\
\hline \multirow{2}{*}{$\begin{array}{l}\text { Information } \\
\text { index }\end{array}$} & $r$ & 0.330 & 0.022 & 0.304 & 0.261 & 0.242 & 0.728 & 1 & & & \\
\hline & $\mathrm{p}$ & $0.001^{*}$ & 0.814 & $0.001^{*}$ & $0.001^{*}$ & $0.001^{*}$ & $0.001^{*}$ & . & & & \\
\hline \multirow{2}{*}{$\begin{array}{l}\text { Quality } \\
\text { index }\end{array}$} & $\mathrm{r}$ & 0.075 & -0.009 & 0.058 & 0.253 & 0.171 & .641 & 0.615 & 1 & & \\
\hline & $\mathrm{p}$ & 0.426 & 0.92 & 0.536 & $0.001^{*}$ & 0.066 & $0.001^{*}$ & $0.001^{*}$ & . & & \\
\hline \multirow{2}{*}{$\begin{array}{l}\text { Precision } \\
\text { index }\end{array}$} & $\mathrm{r}$ & 0.064 & -0.105 & 0.075 & 0.11 & 0.092 & 0.509 & 0.482 & 0.551 & 1 & \\
\hline & $\mathrm{p}$ & 0.492 & 0.263 & 0.421 & 0.239 & 0.325 & $0.001^{*}$ & $0.001^{*}$ & $0.001^{*}$ & . & \\
\hline \multirow{2}{*}{$\begin{array}{l}\text { Total VIQI } \\
\text { score }\end{array}$} & $r$ & 0.179 & -0.027 & 0.159 & 0.287 & 0.239 & 0.867 & 0.838 & 0.848 & 0.742 & 1 \\
\hline & $\mathrm{p}$ & 0.054 & 0.776 & 0.087 & $0.001^{*}$ & $0.001^{*}$ & $0.001^{*}$ & $0.001^{*}$ & $0.001^{*}$ & $0.001^{*}$ & · \\
\hline
\end{tabular}


$\mathrm{MICl}(16,18,24)$. The Discern index measures the written health information, while the $\mathrm{MICl}$ is used to analyze the medical information in videos related to prevalence, clinical symptoms, transmission, testing, and treatment $(16,18,24)$. The $\mathrm{VIOl}$ is a more general index for determining the overall quality of a video (16). Since videos related to dentistry were examined in our study, we found it appropriate to use the $\mathrm{VIOI}$, which allowed us to analyze flow, information, quality, and precision. The $\mathrm{VIOI}$ index queries general video quality while other indices question medical information.

Since 2012, YouTube has been using an algorithm called Dwell Time in video searches. In this algorithm, the ordering of videos is determined by watch duration. If a viewer watches a video for a long period of time, the algorithm ranks the video more highly (25). Accordingly, the first half of the videos we reviewed were deemed HR and the second half LR. When we compared the video quality indices by relevance, information, precision (i.e., appropriate title preparation), and total $\mathrm{VIOI}$ score, the HR group was significantly higher than the LR group. This supports the validity of the YouTube algorithm. However, there was no difference between groups in the flow or quality indices. We posit that this is related to an increase in the quality of videos overall since more people have experience with video preparation, as well as technological improvements.

Since content on the internet is ever-changing, the results of this study offer time-sensitive information, like other cross-sectional investigations. Certain video characteristics, such as number of views and like/dislike ratio, change with every view. Another limitation of the current study was its restriction to English-language video content, which meant that videos in other languages could not be evaluated. Although the "likes" on the videos give some idea of viewers' reactions, the evaluation of viewers' opinions was limited since most videos were not watched by many people. Finally, since the COVID-19 outbreak is highly emergent, there was no other study investigating the subject examined here. As such, we could not compare many of our results with similar studies. These limitations should be taken into consideration in future studies as the numbers and view counts of YouTube videos about dentistry and COVID-19 increase.

This study showed the following results regarding dental YouTube videos during the COVID-19 pandemic period:

Dental YouTube videos from official institutions had higher levels of knowledge and video quality. It will be beneficial for experts, universities, and other institutions to upload sufficient duration YouTube videos with scientific content, especially during COVID-19.

The contents of the videos were found to be insufficient related to dental emergencies and legal-financial issues during the COVID-19 pandemic. There is a need for more videos to be prepared for these contents.

The authors think that videos shared on the Internet, especially in the field of health, should be published after being subjected to an institutional approval and control system. Therefore, it can be beneficial for YouTube to screen and remove the videos during the upload of low-quality videos containing unnecessary/wrong information and increase the relevance of useful videos.

The authors suggest to internet users that they should be incredibly careful while learning about health topics and prefer videos uploaded by corporate sources.

\section{Resumo}

Este estudo teve como objetivo analisar os vídeos disponiveis no YouTube relacionados à odontologia e ao novo coronavírus (COVID-19), visto que não há tal análise na literatura existente. Os termos "dental" e "COVID-19" foram pesquisados no YouTube em 9 de maio de 2020. Os 116 principais vídeos em inglês, com pelo menos 300 visualizações, foram analisados por dois observadores. Os dados foram salvos para cada vídeo, incluindo público-alvo, fonte, país de origem, conteúdo, número de visualizações, tempo assistido, média de visualizações, duração, proporção de gostar/ não gostar e utilidade. As pontuações do indice total de informação e qualidade de vídeo (VIOI) foram calculadas, consistindo em índices de fluxo, informação, exatidão, qualidade e precisão. Testes não paramétricos foram usados para análise. Os vídeos analisados foram assistidos $375 \mathrm{mil}$ vezes e totalizaram $20 \mathrm{~h}$ de conteúdo. A maioria dos vídeos foi enviada por dentistas (45,7\%), com origem nos Estados Unidos (79,3\%) e com informações direcionadas aos pacientes $(48,3 \%)$. Quase metade dos vídeos $(47,4 \%)$ foram moderadamente úteis. Para a utilidade dos vídeos, foram encontradas diferenças estatisticamente significantes para todos os índices, bem como para os escores totais do VIQI. Uma comparação dos indices de acordo com a relevância dos vídeos mostrou diferenças estatisticamente significativas nas informações dos vídeos e nos índices de precisão e nas pontuações totais do VIOI. Os resultados deste estudo mostraram que os vídeos de odontologia no YouTube relacionados à COVID-19 tiveram um alto número de visualizações; no entanto, os vídeos eram geralmente moderados em qualidade e utilidade.

\section{Acknowledgements}

We would like to thank Hande Emir, for the help of statistical analyses of this article.

\section{References}

1. Izzetti R, Nisi M, Gabriele M, Graziani F. COVID-19 transmission in dental practice: Brief review of preventive measures in Italy. J Dent Res 2020;99:1030-1038.

2. WHO. WHO Virtual press conference on COVID-19 [Internet]. World Heal Organ. [cited 2020 Mar 29]. Available from:https://www.who. int/docs/default-source/coronaviruse/transcripts/virtual-pressconference---7-july---covid-19.pdf?sfvrsn=6d4b4eb7_2

3. WHO. Coronavirus disease 2019 (COVID-19) situation report - 141 [Internet]. [cited 2020 Jun 10]. Available from: https://www.who.int/ docs/default-source/coronaviruse/situation-reports/20200609-covid19-sitrep-141.pdf?sfvrsn=72fa1b16_2

4. Peker I, Pamukcu U, Taka K, Ucok O. Diş hekimliği pratiğinde Koronavirüs salgınına karşı alınması gereken önlemler. Turkiye Klin J Dent Sci 2020. doi:10.5336/dentalsci.2020-75270

5. Lu CW, Liu XF, Jia ZF. 2019-nCoV transmission through the ocular surface must not be ignored. Lancet 2020;395:339.

6. Peker I, Ozdede M. İntraoral dijital görüntülemede enfeksiyon kontrolü. Turkiye Klin J Oral Maxillofac Radiol-Special Top 2016;2:55-60. 
7. Alharbi A, Alharbi S, Alqaidi S. Guidelines for dental care provision during the COVID-19 pandemic. Saudi Dent J 2020;32:181-186.

8. Meng L, Hua F, Bian Z. Coronavirus disease 2019 (COVID-19): Emerging and future challenges for dental and oral medicine. J Dent Res 2020;99:481-487.

9. Ozdede M, Bagci N, Peker I. COVID-19 pandemisi döneminde tele-dis hekimligi. Turkiye Klin J Dent Sci 2020 doi:10.5336/ dentalsci.2020-76630

10. Basch CH, Hillyer GC, Meleo-Erwin ZC, Jaime C, Mohlman J, Basch CE. Preventive behaviors conveyed on YouTube to mitigate transmission of COVID-19: Cross-sectional study. JMIR Public Heal Surveill 2020;6:e18807.

11. Keelan J, Pavri-Garcia V, Tomlinson G, Wilson K. YouTube as a source of information on immunization: A content analysis. J Am Med Assoc 2007;298:2482-2484.

12. Alexa. The top 500 sites on the web [Internet]. [cited 2020 Apr 23]. Available from: https://www.alexa.com/topsites

13. Basch $\mathrm{CH}$, Fung ICH, Hammond RN, Blankenship EB, Tse ZTH, Fu KW, et al. Zika virus on youtube: An analysis of English-language video content by source. J Prev Med Public Heal 2017;50:133-140.

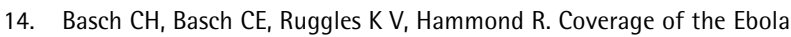
Virus disease epidemic on YouTube. Disaster Med Public Health Prep 2015;9:531-535.

15. Trends G. https://trends.google.com/trends/ explore?date $=2020-01-01 \% 202020-04-22$ [Internet]. [cited 2020 Apr 22]. Available from: https://trends.google.com/trends/ explore?date=2020-01-01 2020-04-22

16. Nagpal SJS, Karimianpour A, Mukhija D, Mohan D, Brateanu A. YouTube videos as a source of medical information during the Ebola Hemorrhagic Fever epidemic. Springerplus 2015;4:1-5.

17. Basch $\mathrm{CE}$, Basch $\mathrm{CH}$, Hillyer $\mathrm{GC}$, Jaime $\mathrm{C}$. The role of YouTube and the entertainment industry in saving lives by educating and mobilizing the public to adopt behaviors for community mitigation of
COVID-19: successive sampling design study. JMIR Public Heal Surveill 2020;6:e19145.

18. Khatri P, Singh SR, Belani NK, Yeong YL, Lohan R, Lim YW, et al. YouTube as source of information on 2019 novel coronavirus outbreak: a cross sectional study of English and Mandarin content. Travel Med Infect Dis 2020;35:101636.

19. Da Silva FR, Madia DS, Passos Martins LF, Cunha NS, Umpierre RN. The visibility and coverage of Primary Health Care videos posted by the nucleous of telehealth and telemedicine, Federal University of Rio Grande do Sul on Youtube between 2012 and 2014. J Bras Tele 2016;4:151-152.

20. Abukaraky A, Hamdan AA, Ameera MN, Nasief M, Hassona Y. Quality of YouTube TM videos on dental implants. Med Oral Patol Oral Cir Bucal 2018;23:463-468.

21. Hassona $Y$, Taimeh D, Marahleh A, Scully C. YouTube as a source of information on mouth (oral) cancer. Oral Dis 2016;22:202-208.

22. Dubey D, Amritphale A, Sawhney A, Dubey D, Srivastav N. Analysis of YouTube as a source of information for West Nile Virus infection. Clin Med Res 2014;12:129-132.

23. Li M, Yan S, Yang D, Li B, Cui W. YouTube as a source of information on food poisoning. BMC Public Health 2019;19:952.

24. Gunduz C, Gurkan 0. Assessment of the educational content of YouTube videos about chest radiograph interpretation. J Basic Clin Heal Sci 2019;3:134-138.

25. Fernandez-Llatas C, Traver V, Borras-Morell J-E, Martinez-Millana A, Karlsen R. Are health videos from hospitals, health organizations, and active users available to health donsumers? An analysis of diabetes health video ranking in YouTube. Comput Math Methods Med 2017;2017:8194940. 